\title{
Foucault's Monsters, the Abnormal Individual and the Challenge of English Law
}

\author{
ANDREW N. SHARPE
}

\section{Introduction}

This article considers the challenge that an English legal history of the category monster poses for Foucault's genealogy of the abnormal individual. While the idea of the monster is not confined to law it is contended that the inauguration of the monster category into English law and its subsequent development provides a useful vantage point from which to critique Foucault's position. While law is only one discourse among others it is a discourse that possesses an authority few others do. A study of the monster as legal category $^{1}$ promises to offer important insights for thinking about questions of difference and exclusion in contemporary life. Michel Foucault has intimated that the idea of the monster operates as a kind of master category for understanding contemporary forms of exclusion, erasure, surveillance and control. Certainly, he understands the idea of abnormality as structured by this much older legal category. ${ }^{2}$

The genealogy of the abnormal individual offered by Foucault, one linking human monsters of old to abnormal individuals of the present, is an important piece of historical scholarship. A study of the legal category monster within English law provides evidence in support of many of Foucault's historical and theoretical claims concerning monsters. In particular, it provides support for the theoretical framework in which Foucault locates an understanding of monsters. However, an English legal history of the monster category suggests a number of important caveats. The article will first consider the idea of the monster in conceptual terms, focusing in particular on understandings of the monster offered by Canguilhem and Foucault. It will then address Foucault's historical treatment of monsters and correspondingly, his genealogy of the abnormal individual. Finally, a legal history of the monster category will be sketched and compared with Foucault's historical account.

\section{A Conceptual Framework}

There is a great deal of literature on the subject of monsters. ${ }^{3}$ It would seem that each culture and all historical periods breed monsters. The monster is, as Cohen suggests, "pure culture." ${ }^{4}$ That 
is, the monster is a cultural construction, either completely fictitious or a designation made in relation to living flesh. Moreover, it would seem that it is living flesh, rather than non-organic types of monster, which arouses the greatest anxiety. Indeed, for Canguilhem "[t]he qualification of monster must be reserved for organic beings." 5 The term monster is another name for hybridity or "otherness within sameness," ${ }^{6}$ and typically refers to a creature that is both, and simultaneously, human and non-human. The term derives from the Latin word monstrare meaning to show forth or demonstrate. ${ }^{7}$ This fact offers an important clue about the monster concept that the article will explore.

In speaking of monsters a considerable degree of conceptual precision is required. This is perhaps especially so when attempting to pinpoint the proper relationship between the linked concepts of monstrosity and the monstrous. The terms monster, monstrosity and monstrousness are often used interchangeably and without distinction in the literature. ${ }^{8}$ Certainly, the precise relationship between these terms is rarely delineated. In thinking about the proper relationship between these terms two texts stand out as aids. These are Canguilhem's seminal work on Monstrosity and the Monstrous, ${ }^{9}$ and the more recent reflections on the subject by Foucault in his text Abnormal. ${ }^{10}$ In Canguilhem's view, monstrosity and the monstrous "are a duality of concepts with the same etymological root" and are "at the service of two forms of normative judgment, the medical and the legal." ${ }^{11}$ For Canguilhem, the monster can be understood conceptually as an amalgam of these two forms of normative judgment. That is, the monster is a creature that is both a monstrosity, understood in terms of morphological irregularity, and monstrous, understood in terms of transgression of the law.

Accordingly, on this account, Shildrick's claim that "what is monstrous about [monsters] is most often the form of their embodiment", what she calls their "aberrant corporeality," ${ }^{12}$ misses the point. It confuses the duality of concepts Canguilhem identifies. On Canguilhem's account what is monstrous about monsters is not the form of their embodiment for this constitutes only a breach of nature. Rather, what is monstrous about monsters lies in transgression of the law. Moreover, for Canguilhem, monstrosity cannot be divorced from monstrousness for the former term always implies the latter. That is to say, monstrosity is the effect produced by monstrousness. For Canguilhem, monstrousness is to be found in the act or acts believed to cause "aberrant corporeality." For as he explains, monstrosity is: 
contingency of life than of the licence of living beings. . . Monstrosity occurred unexpectedly because of lack of discretion . . the result of an animal's carnival. ${ }^{13}$

It is clear from this passage that Canguilhem viewed the act of bestiality as the specific transgression of the law that culminated in morphological irregularity. Crucially, Canguilhem understands monstrosity as produced by, or as the effect of, this particular kind of monstrousness. For Canguilhem, monstrousness equates with a particular act and taboo and responsibility lies with the female agent of monster production. As for monstrosity, it is merely the visible sign and evidence of the mother's transgressive act. ${ }^{14}$ In this respect, monstrosity can be understood as the visible manifestation of monstrousness. That is to say, in monstrosity, monstrousness shows forth or is demonstrated. As a result of understanding the concept of monstrosity exclusively in terms of morphological irregularity, and as the effect of monstrousness, Canguilhem is led to the conclusion that today "life is poor in monsters." ${ }^{5}$ For with the development of science a view of bodily irregularities as having a monstrous cause could no longer be sustained. In other words, "[t]he transparence of monstrosity to scientific thought . . . deprives it of all relationship to the monstrous." 16 Without monstrousness the monster is denied one of its constitutive elements and therefore on Canguilhem's reckoning disappears.

Turning to Foucault, it is clear that he too comprehends the monster as an amalgam of the concepts of monstrosity and monstrousness. Thus in offering an account of the legal distinction between deformity and monstrosity, a distinction traceable to Roman law, ${ }^{17}$ Foucault notes that the monster represents "the transgression of natural limits" and that "this is actually what is involved in monstrosity." ${ }^{18}$ Yet, "[f]or Medieval thought, and definitely for seventeenth and eighteenth century thought" he notes "breach of natural law is not enough to constitute" the monster. ${ }^{19}$ There must also be "an interdiction of civil and religious or divine law" for the monster appears "only when confusion comes up against, overturns, or disturbs civil, canon, or religious law" 20 for "[t]he monster combines the impossible and the forbidden." ${ }^{21}$ To put it differently, "the monster appears and functions precisely at the point where nature and law are joined" for the monster is "a juridico-natural complex." 22 While deformity or disability "may well be something that upsets the natural order" it does not lead to the designation monster because "it has a place in civil or canon law. The disabled person may not conform to nature, but the law in some way provides for him. Monstrosity, however, is the kind of irregularity that calls law into question and disables it." 23 
Elsewhere Foucault explains that a creature is only a monster because "it is a legal labyrinth, a violation of and an obstacle to the law, both transgression and undecidability at the level of the law." ${ }^{24}$ In juxtaposing violation to obstacle and transgression to undecidability, Foucault renders explicit the concept of monstrousness as a constitutive element of the category monster. In addition to a breach of nature, the designation monster requires a breach of the law, and by breach of the law Foucault is referring both to the fact that a particular body renders important legal questions uncertain, indeed undecidable (the body as obstacle to the law), and calls into question the categorical structure of law (the body as violation of the law). Thus, for example, human/animal creatures, conjoined twins and hermaphrodites can be viewed as problematising a variety of legal questions concerning baptism, marriage and inheritance, as well as challenging core legal distinctions between man and animal, male and female, and the idea of the proper legal subject as a single embodied mind. ${ }^{25}$

Thus Foucault shares with Canguilhem a view of the monster as an amalgam of two forms of normative judgment, the medical and the legal. He does not, however, insist on a particular relation and certainly not a causal relation between the concepts of monstrosity and monstrousness. It is true that, like Canguilhem, Foucault places emphasis on the transgressive act of bestiality in explaining historical understandings of irregular bodies designated monsters. ${ }^{26}$ However, this element does not appear to occupy a central place within Foucault's theoretical account. Rather, in thinking about monstrousness in relation to monsters of old, Foucault places less emphasis on transgressive acts than on the nature of the challenge bodies pose to legal certitude and taxonomy. Thus for Foucault the problem of the monster is ultimately not one of causation or responsibility, but one of effects. Foucault's monsters present a problem of classification. Nevertheless, as with Canguilhem's account, monstrosity, understood in this way, can still be thought of in terms of the visible manifestation of monstrousness. For challenge to legal taxonomy is rendered visible by the irregular body.

In thinking about Foucault's analysis of the monster concept more generally what appears central to his account is neither monstrous acts nor irregular bodies, but the fact of a "double transgression," ${ }^{27}$ of law and nature. For Foucault it is simply the co-presence of these two forms of breach that accounts for the birth of monsters. It is precisely this point that enables us to think about the legal category monster as one that informs the figure of the abnormal individual. For Foucault the figure of the monster now functions as a "magnifying model . . . for every little deviation" and 
as "the principle of intelligibility of all the forms that circulate as the small change of abnormality." ${ }^{28}$ Today it is only the normal type, Tarde's "zero of monstrosity," 29 that is distanced from the monster. All those who deviate from the norm bear a relationship by degree to monster status, one that can be endlessly reworked for the purpose of recreating the coherence of human identity. Thus the abnormal individual is a contemporary monster. As with the human monster, his monstrousness is to be understood in terms of transgression of the law. This might manifest iself through transgressive acts bearing taboo status or through challenge to legal taxonomy. The figure of the homosexual may serve as an example here. Thus breach of the law might be found to exist in the act of sodomy and/or in the homosexual's implicit challenge to the heteronormative gender order.

In relation to monstrosity it is no longer to be understood in terms of the externality or materiality of the body. Rather, the monstrosity of the abnormal individual lies in interiority or psyche. For what is now sought within regimes of normalisation is "the core of monstrosity hidden behind little abnormalities, deviances and irregularities," ${ }^{30}$ a monstrosity that "does not produce its effects in nature and the confusion of species, but in behaviour itself." ${ }^{31}$ In other words, Foucault's genealogy of the abnormal individual serves to foreground a shift from the body to the soul as the object of legal concern. Accordingly, in contrast to monstrosity written on the surface of irregular bodies, the abnormal individual's monstrosity is of an invisible kind. With the arrival of the abnormal individual we witness the disappearance or rather the internalisation of monstrosity. In the context of the abnormal individual, monstrosity can no longer be understood as the visible manifestation of monstrousness. It is precisely this fact of invisibility, where monstrousness is not shown forth or demonstrated, that constitutes the abnormal individual as a figure of modernity. Accordingly, this displacement and re-institutionalisation of the concept of the monster has served to uncouple it from its own etymology.

As we will see, an English legal history of the category monster provides support for many of the theoretical claims made by Canguilhem and Foucault. Certainly, English legal monsters appear as the effect of a double breach, of nature and law, or as an amalgam of two forms of normative judgment, the medical and the legal. Moreover, and while not crucial for Foucault's account, an assumption of bestiality as cause of monstrosity appears to underpin and typify English legal understandings of the monster category. These theoretical accounts are important to an understanding of the monster category within English law. However, in other respects English law poses a challenge to Foucault's account of monsters. 
The difficulty with Foucault's account lies not in his conceptual understanding of the monster. Rather, the difficulty, as this article will demonstrate, pertains to his history of monsters and correspondingly to his genealogy of the abnormal individual.

\section{Foucault's History of Monsters}

In addition to providing a useful conceptual framework for making sense of monsters, Foucault offers a history of human monsters. It should be conceded from the outset that the history he offers is a French history. It is not my intention to call into question that history on account of differences that exist between English and French law. To do so would fail to take into account historical and cultural differences that exist between England and France, as well as the different legal traditions that animate each nation. ${ }^{32}$ Rather, what is being challenged is the degree to which Foucault's history provides an adequate account for the emergence and comprehension of the abnormal individual. While Foucault's history of French law might be accurate in itself, conclusions drawn from it that inform our understanding of contemporary regimes of normalisation are open to a critique based on an analysis of English law. For the figure of the abnormal individual is not confined to France but is rather a figure of modernity.

According to Foucault's history each age had its "privileged monster." 33 In chronological terms his account moves from a preoccupation with bestial man (the mixture of species) in the Middle Ages to a concern over Siamese or conjoined twins (the mixture of individuals) in the Renaissance and ultimately to a focus on the hermaphrodite (the mixture of sexes) in the Classical age. ${ }^{34}$ Yet, in relation to English law we will see that this account proves inadequate. Whatever may have been the case outside England, and whatever may have been the view of monsters within popular culture and non-legal discourses, including medical discourses, within England, it is clear that an English legal history of monsters presents a different and more complex picture both in terms of its scope and chronology. Moreover, the hermaphrodite was never considered a monster within English law. ${ }^{35}$

The difficulty with Foucault's historical account of monsters is not confined to a concern to accurately represent a legal past. Rather, Foucault's project is a genealogical one that seeks to account for the emergence of a particular contemporary figure, which he described as the abnormal individual. Thus in his study of abnormality, Foucault provides a complex genealogy for the abnormal individual, one highlighting three key ancestors: the human monster, incorrigible man, and the masturbating child. ${ }^{36}$ 
During the second half of the eighteenth century "the monster, the incorrigible and the masturbator are characters who begin to exchange some of their traits and whose profiles begin to be superimposed on each other." 37 Thus, and by way of example, Foucault notes that within this period masturbation comes to be considered the cause of "physical deformities" as well as one of "the worst kinds of monstrous behavior," while correctional institutions focus increasingly on "sexuality and masturbation as fundamental to the problem of the incorrigible." 38 Yet, he insists, these characters "remain absolutely distinct and separate until the end of the eighteenth and the beginning of the nineteenth century." 39

According to Foucault "a technology of abnormal individuals appears precisely when a regular network of knowledge and power has been established that brings the three figures together." ${ }^{40}$ On this account the constitution of the abnormal individual is the effect of the systematisation, codification and linkage of three bodies of knowledge and power: natural history, pedagogical techniques, and the biology of sexuality. ${ }^{41}$ A shift in legal concern from the human monster to the abnormal individual is to be understood as "a process that develops between 1765 and 1820-1830" 42 and is to be accounted for by a transformation in "politico-judicial powers" ${ }^{43}$ exemplified, perhaps, by a transformation in "the economy of punitive power." ${ }^{44}$ For present purposes, what is significant about Foucault's genealogy is the manner in which he links the subject of contemporary regimes of normalisation to a series of antecedent figures, and in particular to the figure of the human monster. What needs to be emphasised is his contention that the organising principles of the legal category monster not only structure understandings of the human monster but also structure understandings of each of the marginalised figures that have succeeded him into the present.

Thus far I have little objection to Foucault's historical analysis. On the contrary it has much to commend it. My difficulty with Foucault's history lies with his account of the figure of the human monster, and specifically, his insistence that the emergence of human monster types followed a particular sequence. As already noted, Foucault charts a shift in legal concern from bestial man in the Middle Ages to a concern over Siamese or conjoined twins in the Renaissance and ultimately to a focus on the hermaphrodite in the Classical age. My point here is not to restate that such a chronology is at odds with English legal history. Rather, it is to highlight the implications of such a disjunction for the endpoint of Foucault's history, the abnormal individual. It is contended that Foucault's sequencing of monsters presents a linear history in which the notion of the human monster as absolute difference takes on an 
increasingly relative character. That is to say, his historical account begins with the problem of human/animal hybridity. This problem is then exchanged for the conundrum of the human creature with two heads, and subsequently for the ambiguously sexed body. This account implies a gradual lessening of the physical and psychological distance between human being and the figure of the monster. Moreover, such an account enables Foucault to position the abnormal individual and contemporary regimes of normalisation within this frame of historical continuity. Conversely, a history of the English legal category monster suggests a more complex relation between human and monster. Indeed, it would appear that the trend, implicit in Foucault's account, of a lessening of physical and psychological distance between human and monster, moves in the opposite direction within English law.

\section{An English Legal History of Monsters}

The legal category monster entered English law in the midthirteenth century in the common law writings of Bracton and Britton. In On the Laws and Customs of England, Bracton, in defining legal personhood, states that "those procreated perversely, against the way of human kind, as where a woman brings forth a monster or a prodigy" shall "not [be] reckoned among children." 45 However, and in providing some sense of the parameters of thirteenth century legal monsters, Bracton notes that "an offspring who has a larger number of members, as one who has six fingers, or if he has but four [or only one], will be included among children." ${ }^{46}$ Nor will a child be considered a monster because it is "crooked or humpbacked or has twisted limbs or otherwise has its members useless." ${ }^{47}$ However, in a passage not directed toward addressing the question of monster status, Bracton expressed the view that the church does not have "several heads like a monster" 48 thereby suggesting that he considered conjoined twins to be monsters.

In short, Bracton's classificatory scheme distinguished between monstrosity (and therefore bodies located outside the law) and deformity (where bodies were located within the law). In doing so Bracton appears to have followed Roman law. ${ }^{49}$ The later thirteenth century writings of Britton replicate Bracton's taxonomy. Thus children born with a lesser or greater number of fingers than is usual are not reckoned monsters. In throwing further light on where the line is perhaps to be drawn, Britton states that children born with "three hands or feet . . shall not be admissible to any inheritance, or [be] accounted children." ${ }^{50}$ Thus, and consistent with the analyses of Canguilhem and Foucault, the production of 
monsters in thirteenth century English law was tied to anxieties concerning imagined breaches of nature and law. That is to say, the elements of the monsters that appear in this period are an irregular morphology and the assumed practice of bestiality. ${ }^{51}$ Moreover, it is precisely these elements that continue to structure the production of English legal monsters thereafter.

After entering English law in the thirteenth century in the writings of Bracton and Britton the term monster did not reappear until the late-sixteenth century. ${ }^{52}$ In 1590 in a canon law text titled $A$ Brief Treatise of Testaments and Last Wills the term is re-presented by Henry Swinburne, lawyer and part-time judge of the Consistory Court at York. According to Swinburne:

where a wife do bring forth a monster, or misshapen creature, having peradventure a head like unto a dogs head, or to the head of an ass, or of a raven, or duck, or of some other beast, or bird: such monstrous creature, though it should live (as commonly none do) yet it is not accounted amongst the testators children, for the law doth not presume that creature to have the soul of a man, which hath a form and shape so strange and different from the shape of a man. ${ }^{53}$

\section{He continues:}

[b]ut if the creature brought forth, do not vary in shape from a man or woman, but have somewhat more than God by the ordinary course of nature alloweth, as having six fingers on either hand, or one foot: such creature is not excluded, but is to be accounted for the testator's child. ${ }^{54}$

The figure of the monster next appears in English law in the writings of John Cowell and the distinguished common law jurist, Sir Edward Coke. In the first part of his Institutes of the Laws of England, written in the early seventeenth century, Coke states: "[a] monster, which hath not the shape of mankind, cannot be heire or inherit any land, albeit it be brought forth within marriage . . . but although he hath deformity in any part of his body, yet if he hath human shape he may be heire." 55

While this passage offers little assistance as to where the line between deformity and monstrosity is to be drawn, John Cowell, writing in 1605, articulates more clearly a Bractonian understanding of the distinction. That is, while "those who are brought forth contrary to the form of mankind ... as monsters and prodigies in nature" are neither legitimate or reputed children, "those which are irregular only in members, as having six fingers, or four, or only one, shall not for that be esteemed illegitimate." ${ }^{56}$ The next English legal text referring to the legal category monster, and the last unique rendition of the category, is to be found in the mideighteenth century common law writings of William Blackstone. ${ }^{57}$ In relation to monsters Blackstone declared: 
[a] monster, which hath not the shape of mankind, but in any part evidently bears the resemblance of the brute creation, hath no inheritable blood, and cannot be heir to any land, albeit it be brought forth in marriage: but although it hath deformity in any part of its body, yet if it hath human shape, it may be heir. ${ }^{58}$

This legal history is interesting in many respects. Of course, the authorities cited are few in number. Nevertheless, they include the legal writings of Bracton, Coke and Blackstone, the most important common law jurists in English legal history. Their works represent the most important collections of English common law compiled between the late Middle Ages and the Enlightenment. Lest it be thought that their representations of monsters were idiosyncratic and out of step with broader legal understandings of monsters in particular historical moments, it should be appreciated that each of their texts represented, in sequential fashion, English law for centuries. From a perspective internal to English law, Bracton, Coke and Blackstone were the law of England. Had their monster texts been viewed as legally problematic it is likely that dissensus would have led to the production of a greater number of legal texts on monsters.

A deeper appreciation of the legal history presented would require locating each legal text within its socio-political context. As Cohen notes, the successful disavowal of monsters at the societal level requires both "a degree of cultural uniformity and relative social calm." 59 These features appear to have been absent in moments of English legal monster production. Thus Bracton's text emerged within a period characterised in terms of a "quest for intellectual and institutional uniformity and corporatism throughout Europe." 60 It was a period that witnessed the emergence of a nascent English state, ${ }^{61}$ a drive toward orthodoxy within Christian theology and practice, and a time when religious crusades, and their failure, weighed heavily in the West on the collective imagination. ${ }^{62}$ Equally, the late sixteenth century writings of Henry Swinburne need to be situated within the political and theological context of the English Reformation and Counter-Reformation. During the period of the Reformation, both in England and in Europe, literature on monsters proliferated and was deployed by both sides of the religious struggle and for the purposes of that struggle. ${ }^{63}$ The suggestion that Swinburne's text is to be understood in this way finds support in the animal symbolism of the creatures he identifies. That is, his dog, ass and raven-headed creatures lend themselves to a set of contemporaneous meanings that revolve around religious themes. Thus in both the medieval and early modern periods the dog was associated with the devil and the ass with the Jew. ${ }^{64}$ Equally, the figure of the raven pointed to (religious) war, death and the afterlife. As noted by Fleming, in 
Western Europe, "ravens appear almost exclusively as signatory animals for deities," ${ }^{65}$ that is, as portents. In relation to the monster text in Coke's Institutes it might be understood in the context of socio-political anxieties preceding the English Civil War. As for Blackstone, his monster might be understood as an allegory for the common law, standing as it does in opposition to the dictates of the Enlightenment. For Blackstone was a social conservative who preferred law's mystery to "the devouring gaze of reason." ${ }^{66}$ Such a view is, perhaps, reinforced by the Gothic aesthetic which informs his Commentaries. ${ }^{67}$

These suggested linkages may be important to an understanding of the English legal history of monsters. However, the proper location of these legal texts requires further historical inquiry. For the purposes of this article what is important is not the social forces that account for the specificity of particular constructions of monsters, but the trajectory of monster production. For the article is less concerned with the causes of the appearance of monsters than with their effects. While there is a degree of unevenness in English law, the trend in the legal construction of monsters is one where monsters became increasingly fantastic over time. Thus in the late Middle Ages, when the category first entered English law, monsters possessed something of a matter-of-fact quality. That is, they seem to accord with embodied reality, albeit one of corporeal excess. Thus humans born with three hands or feet ${ }^{68}$ or two heads ${ }^{69}$ were adjudged monsters. This is not to suggest that the human/animal distinction proved irrelevant to an understanding of monsters for legal jurists of the thirteenth century. On the contrary, and consistent with the analyses of Canguilhem and Foucault, it seems reasonably clear that Bracton and Britton attributed the existence of monsters to the practice of bestiality. ${ }^{70}$ Nevertheless, the legal monsters produced in thirteenth century England lacked any specifically animal features. That is to say, for Bracton and Britton, a concern with animality was confined to aetiology. Animality was simply not written on the bodies of their monsters. In this regard, English legal history does not support Foucault's claim that it was bestial man who was the "privileged monster"71 of this period.

By the time of the Renaissance the monster category had expanded to include human/animal hybridity. Thus in the writings of Henry Swinburne the legal monster of corporeal excess is supplemented by dog, raven and duck-headed human creatures. ${ }^{72}$ For Swinburne, monsters are not confined to creatures considered to be the product of inter-species copulation. Rather, monsters extend to creatures that bear the authorial mark or imprint of two different species. Moreover, Swinburne not only introduces human/animal hybridity to the monster category of English law. He also fore- 
grounds the visibility of human/animal hybridity as emblematic of monstrosity. This is especially apparent in his location of the human/animal monster at the apex of a monster hierarchy. Thus, in contrast to his view that excessive or disordered bodies are not necessarily monsters, he harboured no doubt as to the monster status of human/animal hybrids. For it was only the legal status of the former that Swinburne viewed as involving a question of judicial discretion. ${ }^{73}$ In contrast, in the writings of Coke and Cowell something of a reversion to a Bractonian understanding of monsters is apparent. However, while these seventeenth century jurists do not articulate a monster whose corporeal surface expresses human/animal hybridity, is is apparent that bestiality is viewed as the cause of monstrosity. Moreover, this is rendered more explicit by Coke than by thirteenth century legal jurists. Thus in his treatment of the crime of buggery, Coke notes that prior to a 1533 statute criminalising the act, "a great Lady had committed buggery with a Baboon, and conceived by it." 74 Nevertheless, while his reference to bestiality implies that the human/animal distinction is important to his understanding of what causes monstrosity, Coke's concern does not appear to move beyond the aetiological and, like Swinburne's, encompass the horrifying visible embodiment or spectacle of human/animal hybridity.

By the time of the eighteenth century we might have expected law's human monsters to fade from view. After all, from the late sixteenth century scientific discourse had gradually been removing the epistemological ground from beneath the feet of monsters. That is, from the writings of Ambroise Pare in $1573^{75}$ monsters were increasingly naturalised within medical science. Indeed, and as observed by Daston, in the course of the sixteenth and seventeenth centuries understandings of monsters "swung from the almostsupernatural extreme of portents to the almost-natural extreme of Baconian facts." 76 Yet, by the time of the Enlightenment, rather than the disappearance of monsters, we witness, in the Commentaries of William Blackstone, the reduction of monsters precisely to human/animal hybridity. In this regard, the Blackstonian monster is less than an act of fidelity to his noted sources, namely Bracton and Coke. ${ }^{77}$ Not only does it seem clear that Blackstone held the view that "a monster is the product of animal paternity," ${ }^{\prime 7}$ he also understood the monster exclusively in terms of the visibility of human/animal hybridity. Moreover, unlike Swinburne, Blackstone's concern over human/animal hybridity was not confined to the head. Rather, it included a human creature that "in any part" 79 bore resemblance to animality. In other words, unlike Swinburne's, Blackstone's anxiety over human/animal hybridity cannot be reduced to a concern over the status and metaphorical power of the 
head in understanding human status. This, in itself, is of interest given the status that reason commanded in the Enlightenment period. Rather, for Blackstone, any degree of animality proved sufficient to label a human creature a legal monster. In this regard, Blackstone's text, rather than signaling a departure from a less rational legal past, appears as the most hysterical and fantastical moment in English legal monster production.

While Blackstone's text represents the last unique rendition of the legal category monster, it was not the final enunciation of the category within English law. Blackstone's Commentaries, and his particular human/animal hybrid construction of the monster, appear to have survived as authoritative texts until at least the mid-nineteenth century. After his death over twenty editions of his Commentaries were published in England, ${ }^{80}$ each of which replicates his monster category. Lest it be thought that these texts, at the time of their publication, were nothing more than historical documents, it should be appreciated that Blackstone's Commentaries exerted an important influence on the subsequent development of English law. Moreover, subsequent editions of his Commentaries were not merely faithful reproductions; they note departures occasioned by changes in the law. ${ }^{81}$ Accordingly, Blackstone's figure of the human/animal hybrid continued to resonate as the exclusive locus of the monster within the English legal imaginary well into the nineteenth century.

The finding that the legal construction of monsters became increasingly fantastic over time and that law became increasingly concerned with human/animal hybridity with the coming of modernity serves to raise some important questions. One such question concerns determining how much weight and influence should be given to the legal category monster and, in particular, to the figure of the human/animal hybrid in understanding the contemporary figure of the abnormal individual. A history of the legal category monster provides evidence to suggest increasing legal anxiety concerning the boundary between human and animal. Of course, growing anxiety of this kind has been well documented in broader cultural terms from at least the early modern period ${ }^{82}$ when scientists and intellectuals began "to break down the rigid boundaries between animals and man which earlier theorists had tried to raise." ${ }^{83}$ The contention here is that an intensification of anxiety over the boundaries between human and animal is not only internal to law, but resides precisely within a category of the law that, according to Foucault, operates as the model for understanding all forms of contemporary abnormality.

This claim does not serve to undermine the theoretical strength of Foucault's work. On the contrary, the insights offered by a study 
of English law give additional weight to Foucault's conceptual framework generally and, more specifically, to its application to the figure of the abnormal individual. That is, a history of the legal category monster provides added impetus to Foucault's claim that the abnormal individual is an effect of a double breach, of law and nature. However, this legal history also provides a vantage point from which to reassess the importance of breach of nature to an understanding of the constitution of the abnormal individual. For an English law pre-history of the abnormal individual moves toward rather than away from human/animal hybridity, and therefore toward a more profound breach of the laws of nature. This requires us to consider the possibility that the trope of the unnatural might be more important to an understanding of the construction of the abnormal individual than Foucault's analysis suggests.

It is precisely a reconsideration of the relationship between the (ab)normal and the (un)natural in constituting this contemporary figure that an English legal history of monsters invites. While further historical inquiry is required here, we might expect this history, and growing anxiety over the human/animal distinction which it suggests, to have insinuated itself into the figure of the abnormal individual to a greater degree, and possibly with different cultural consequences, than Foucault's analysis implies. If so, this would serve to emphasise greater continuity between the abnormal individual and his most recent English law ancestor. This claim perhaps derives support from the fact that English legal monsters survived into the mid-nineteenth century. That is to say, the human/animal hybrid should not be thought of simply as part of the abnormal individual's pre-history. For when viewed from the perspective of English law it is clear that the human/animal hybrid and the abnormal individual co-exist and overlap.

\section{Conclusion}

This article has considered Foucault's history of the monster in relation to a history of this category offered by English law. While Foucault's conceptual framework for making sense of monsters finds support in English legal texts, these texts simultaneously pose a challenge for his historical account of monsters. Thus bestial man, the figure Foucault places at the heart of the western psyche in the Middle Ages, appears noticeably absent in thirteenth century legal texts. ${ }^{84}$ Rather, these texts appear confined to human bodies characterised by corporeal excess. Moreover, and in contrast to Foucault's account, the importance of the human/animal hybrid within English law increases over time culminating in Blackstone's reduction of law's monsters to precisely this figure. Accordingly, 
England's legal monsters take on an increasingly fantastical quality over time as they move toward their eventual death. In this respect Blackstone's text seems particularly significant in that it represents not merely a departure from, but a rupture in, a Foucauldian history in which the notion of the monster as absolute difference takes on an increasingly relative character.

It is this finding that is perhaps especially significant. For English legal history does not suggest a gradual relativisation of the difference between human and monster. While Foucault is correct to emphasis genealogical links between the human monster and the abnormal individual, his emphasis on a gradual shift away from the notion of the monster as absolute difference in this process of transformation is problematised by an analysis that looks to English law. For English law appears to have privileged human/ animal hybridity in its construction of monsters over time, and therefore to have placed emphasis on a breach of nature of the most profound kind. The insight offered by this legal history is one that points to the possibility that the trope of the unnatural might be more important to an understanding of the construction of the abnormal individual than Foucault's analysis suggests. In other words, a history of the English legal category monster points to the need to consider the precise relationship between constructions of nature and their breach, and the production of abnormal individuals. Moreover, from the position of English law it might be suspected that the trope of the unnatural operates as a tension within normalising regimes. Indeed, constructions of nature and their deployment might be understood as a limit to this very project of modernity.

\section{Notes}

1 The idea of the monster as legal category has its origins in Roman law. Thus there are references to monsters in a number of specific contexts in the Digest and the Code. In particular, the question of monsters is addressed in the writings of Paul (D.1.5.14), Ulpian (D.50.16.38; D.50.16.135) and Justinian (C.6.29.3). See A. Watson, (ed) The Digest of Justinian (Philadelphia: University of Pennsylvania Press, 1985).

${ }^{2}$ Michel Foucault, Abnormal: Lectures at the College De France 19741975 (London: Verso, 2003) 324. While Foucault's lectures were not published in his lifetime they represent his only text that deals in an explicit and sustained manner with the idea of the monster. Moreover, the theoretical and historical analysis Foucault offers represents a significant analysis of the monster category within social theory. In the words of Valerio Marchetti and Antonella Salomoni the text "Abnormal offers not only a very clear trace of [Foucault's] dossiers and manuscripts but it also allows us to reconstitute what has been lost" ('Course Context' in Abnormal 331-351 at 333). 
${ }^{3}$ See, for example, Mark Neocleous, The Monstrous and the Dead: Burke, Marx, Fascism (Cardiff: University of Wales Press, 2005); Bettina Bildhauer and Robert Mills, The Monstrous Middle Ages (Cardiff: University of Wales Press, 2003); David Gilmore, Monsters: Evil Beings, Mythical Beast, and all Manner of Imaginary Terrors (Philadelphia: University of Pennsylvania Press, 2003); Margrit Shildrick, Embodying the Monster: Encounters with the Vulnerable Self (London: Sage, 2002); Timothy Beal, Religion and its Monsters (New York: Routledge, 2002); Elaine Graham, Representations of the Post-Human: Monsters, Aliens and Others in Popular Culture (Manchester: Manchester University Press, 2002); Edward Ingrebretsen, At Stake: Monsters and the Rhetoric of Fear in Public Culture (Chicago: University of Chicago Press, 2001); Alice Domurat Dreger, Hermaphrodites and the Medical Invention of Sex (Harvard University Press, 2000); Nina Lykke and Rosi Braidotti, Between Monsters, Goddesses and Cyborgs: Feminist Confrontations with Science, Medicine and Cyberspace (London: Zed Books, 1996); David Williams, Deformed Discourse: The Function of the Monster in Medieval Thought and Literature (Exeter: Exeter University Press, 1996); Jeffrey Cohen, Monster Theory: Reading Culture (Minneapolis: Minnesota University Press, 1996); Marie-Helene Huet, Monstrous Imagination (Cambridge, Mass: Harvard University Press, 1993); Arnold Davidson, 'The Horror of Monsters' in The Boundaries of Humanity: Humans, Animals, Machines (Berkeley: California University Press, 1991); Katherine Park and Lorraine Daston, 'Unnatural Conceptions: The Study of Monsters in Sixteenth- and Seventeenth-Century France and England' (1981) 92 Past and Present 20.

${ }^{4}$ Cohen supra note 3 at 4.

5 Georges Canguilhem, 'Monstrosity and the Monstrous' (1964) 40 Diogenes 27 at 28. See also Shildrick, supra note 3 at 10.

${ }^{6}$ Beal supra note 3 at 4.

7 Julia Epstein, Altered Conditions: Disease, Medicine, and Storytelling (London: Routledge, 1995) 91.

8 See, for example, Laura Lunger Kruppers and Joan B. Landes, Monstrous Bodies/Political Monstrosities in Early Modern Europe (New York: Cornell University Press, 2004); Shildrick supra note 14 at 9; Barbara Creed, 'Woman as Monstrous Womb: The Brood' in The MonstrousFeminine: Film, Feminism, Psychoanalysis (London: Routledge, 1993) 43-58.

${ }^{9}$ Canguilhem supra note 5 at 27.

10 Foucault supra note 2.

11 Canguilhem supra note 5 at 30.

12 Shildrick supra note 3 at 9.

13 Canguilhem supra note 5 at 30-31.

14 The emphasis on bestiality as cause of monstrosity and on the role of woman in this conjugal act, as well as the alternative theory of the maternal imagination, whereby a pregnant woman's thoughts were imprinted onto the body of her offspring, draw attention to the relevance of the monster category to feminist theory (see Graham supra note 3 at 52; Rosi Braidotti, 'Signs of Wonder and Traces of Doubt: On Teratology and Embodied Differences' in N. Lykke and R. Braidotti supra note 3 at 135152; Huet supra note 3).

15 Canguilhem supra note 5 at 41.

${ }^{16}$ Id at 38.

17 The Digest of Justinian supra note 1. 
${ }^{18}$ Foucault supra note 2 at 63.

19 Id.

20 Id.

${ }^{21} \mathrm{Id}$ at 56.

${ }^{22} \mathrm{Id}$ at 65.

${ }^{23} \mathrm{Id}$ at 64.

${ }^{24} \mathrm{Id}$ at 65.

${ }^{25} \mathrm{Id}$ at 64-65.

${ }^{26}$ Id at 64.

27 Id at 324 .

$28 \mathrm{Id}$ at 56.

29 Gabriel Tarde, L'opposition Universelle (1897) (quoted by Canguilhem supra note 5 at 29).

${ }^{30}$ Foucault supra note 2 at 56.

${ }^{31}$ Id at 74 .

32 The common law tradition of England can be contrasted with the civil law systems of continental Europe in general. In contrast to most of continental Europe which received Roman law in the late Middle Ages after Justinian's texts (supra note 1) had been rediscovered, the common law proved more resistant to the incorporation of Roman law (see Donald R. Kelley, The Human Measure: Social Thought in the Western legal Tradition (Cambridge, Massachusetts: Harvard University Press, 1990)).

${ }^{33}$ Foucault supra note 2 at 66. See also Stuart Elden, 'The Constitution of the Normal: Monsters and Masturbation at the College of France' (2001) 28(1) Boundary 2 91, 96; Sharon Cowan and Stuart Elden, 'Words, Desires and Ideas: Freud, Foucault and the Hermaphroditic Roots of Bisexuality' (2002) 13 PLI (the Warwick Journal of Philosophy) 79 at 91.

${ }^{34}$ Id at 66-67.

35 This point is rendered explicit in Bracton infra note 45 vol 2 at 31 , Coke infra note 55 vol 1 at 8.a. and Wood infra note 57 at 12 .

${ }^{36}$ Foucault supra note 2 at 60.

37 Id at 61.

${ }^{38}$ Id at $60-61$.

39 Id.

${ }^{40} \mathrm{Id}$. The scientific project of normalisation is one well documented by Foucault (Michel Foucault, The Birth of the Clinic (trans. A.M. Sheridan) (New York: Random House, 1973); Discipline and Punish: The Birth of the Prison (trans. A.M. Sheridan) (New York: Vintage, 1977); The History of Sexuality Vol 1 (London: Vintage, 1980); 'The Dangerous Individual' in Michael Foucault: Politics, Philosophy, Culture Interviews and other Writings 1977-1984 (ed L. Kritzman) (New York: Routledge, 1988) 125-151.

41 Id at 62.

42 Id at 74.

43 Id at 61 .

$44 \mathrm{Id}$ at 82.

${ }^{45}$ Henry de Bracton, On the Laws and Customs of England 1240-1260 vols 1-4 (trans. Samuel E. Thorne) (Cambridge, Mass: Harvard University Press, 1968) vol 2 at 31 . It should be noted that there is some uncertainty regarding the authorship of this text. According to the Harvard Law School Library online it would seem that the bulk of the work was written in the 1220s and 1230s by persons other than Bracton, though it was probably Bracton who made the later additions. Henry de Bracton was a judge of the court known as Coram Rege (later known as the King's Bench) 
from 1247-1250 and 1253-1257 during the reign of Henry III. He was also a clergyman and in 1264 became Archdeacon of Barnstaple and Chancellor of Exeter Cathedral. Bracton's text can be accessed online at http://hlsl.law.harvard.edu/bracton/Common/index.html Date accessed: 14 April 2006. For a discussion of Bracton's work see H.G. Richardson, Bracton: The Problem of his Text (London: Selden Society, 1965).

${ }^{46} \mathrm{Id}$.

47 Id vol 4 at 361.

${ }^{48}$ Id vol 3 at 221. This reference to monsters emerges in the context of Bracton's discussion of the Assise of Darrein Presentment.

${ }^{49}$ Id vol 2 at 31-32. In the margins of his text on monsters, Bracton cites Azo, an early thirteenth century glossator of Roman law. However, it would be mistaken to reduce an understanding of the Bractonian monster to the reception of Roman law. As is well known the reception of Roman law was considerably more limited in England than in continental Europe and it is apparent that Bracton's usage is selective rather than wholesale. There has been debate among legal historians as to the degree to which Bracton's text is Roman. While Guterbock places special emphasis on the importance of Roman law in Bracton's text (Karl Guterbock, Bracton and his Relation to the Roman Law: A Contribution to the History of the Roman Law in the Middle Ages (Littleton, Colorado: Rothman, 1979), more recent legal scholarship has emphasized its Englishness adopting Maitland's view that though "Romanesque in form" it was "English in substance" being based on a vast amount of judicial experience, including some five hundred decisions (Kelley supra note 32 at 167).

${ }^{50}$ Britton, vol 1 (trans. F.M. Nichols) (Florida: Wm. W. Gaunt \& Sons, 1983) at paragraph 19. There is considerably more uncertainty regarding the identity of Britton. However, it would seem that the Britton text was published around 1291 in the reign of Edward I and with the King's express authority. According to Nichols, Edward I desired a comprehensive treatise on the law of England. It was in this context that legal texts by Britton, Fleta and an abridgment of Bracton by Gilbert de Thornton came into being. Only Bracton however, came into general use.

${ }^{51}$ For further evidence on this point see Bracton supra note $45 \mathrm{vol} 4$ at 361; Britton supra note 50 at paragraph 19.

52 Thus there is no mention of monsters in the fifteenth century legal writings of Sir Thomas Littleton (c1410-1481 and judge from 1466) Tenures (London: Richard Tottell, 1557) and Sir John Fortescue (c1395c1477 and Chief Justice of the King's Bench from 1442) On the Laws and Governance of England 1468-1471 (ed) Shelley Lockwood (Cambridge: Cambridge University Press, 1997).

${ }^{53}$ Henry Swinburne, A Brief Treatise of Testaments and Last Wills (1590) 168 (New York \& London: Garland Publishing, 1978).

${ }^{54}$ Id at $168-169$.

55 Sir Edward Coke, The Institutes of the Laws of England vols 1-4 1628-1644 (1832 edn) (New York \& London, Garland Publishing, 1979) vol 1 at $7 . b$.

56 John Cowell, The Institutes of the Laws of England (1605) (New York \& London, Garland Publishing, 1978) 16.

57 Indeed, after Coke there appears to be no reference to monsters in English legal texts prior to Blackstone. Thus, for example, the category of monster does not appear in the work of William Noy, The Grounds \& Maxims of the English Law (1641) (London: H. Linoth, 1757); John Selden, 
Ad Fletam Dissertatio (1647) (Buffalo: William S. Hein \& Company, 1980); John Warr, The Corruption \& Deficiency Of The Laws Of England (London: R. Dutton, 1649); Sir Matthew Hale, The Analysis of the Law: Being a Scheme, ar Abstract of the Several Titles and Partitions of the Law of England, Digested into Method (1650) (Chicago: Chicago University Press, 1971); Roger North, A Discourse on the Study of Laws (1650) (London: White, 1824); John Brydall, Enchiridion Legum: A Discourse Concerning the Beginnings, Nature, Difference, Progress and Use of Laws in General; and in Particular of the Common and Municipal Laws of England (1673) (New York \& London: Garland Publishing, 1978); John Selden, Jani Anglorum Facies Altera (London: T. Bassett, 1683) or Thomas Wood, An Institute of the Laws of England or the Laws of England in their Natural Order According to Common Use (1724) (New York and London: Garland Publishing, 1979).

58 William Blackstone, Commentaries on the Laws of England, vols 1-4 (1765-1769) Vol 2 Of The Rights Of Things (Chicago: University of Chicago Press 1979) Chp 15, 246-247 (my emphasis). Blackstone's Commentaries can be accessed online through Yale University's Avalon project at http:// www.yale.edu/lawweb/avalon/avalon.htm Date accessed: 10 June 2006.

59 Jeffrey Cohen, Of Giants: Sex, Monsters, and the Middle Ages (Minneapolis: University of Minnesota Press, 1999) 4.

60 John Boswell, Christianity, Social Tolerance and Homosexuality: Gay People in Western Europe from the Beginning of the Christian Era to the Fourteenth Century (Chicago: Chicago University Press, 1980) 270. See also R.I. Moore, Formation of a Persecuting Society: Power and Deviance in Western Europe, 950-1250 (Oxford: Basil Blackwell, 1987); R.I. Moore, 'Heresy, Repression, and Social Change in the Age of Gregorian Reform' in Scott L. Waugh and Patrick D. Diehl (eds) Christendom and its Discontents: Exclusion, Persecution and Rebellion, 1000-1500 (Cambridge: Cambridge University Press, 1996) 19.

61 Ernst H. Kantorowicz, The King's Two Bodies: A Study in Medieval Political Theology (New Jersey: Princeton University Press, 1957) 191.

${ }^{62}$ In the period between the writings of Bracton and Britton Edward I returned from the failed crusade in the Holy Land and was crowned King in 1274. In relation to European antipathy toward Islam during the period of the crusades see N. Daniel, Islam and the West: The Making of an Image (Edinburgh: Edinburgh University Press, 1960); N. Daniel, Islam, Europe \& Empire (Edinburgh: Edinburgh University Press, 1966); W.M. Watt, The Influence of Islam on Medieval Europe (Edinburgh: Edinburgh University Press, 1972); R. W. Southern, Western Views of Islam in the Middle Ages (Cambridge, Mass: Harvard University Press, 1978); Michael Uebel, 'Unthinking the Monster: Twelfth-Century Responses to Saracen Alterity' in Cohen supra note 3.

${ }^{63}$ See Shildrick supra note 3 at 12.

${ }^{64}$ Beryl Rowland, Animals with Human Faces: A Guide to Animal Symbolism (London: Allen \& Unwin, 1974) 26, 60.

65 Samantha Fleming, 'Murders and Unkindness' (1998) 19 White Dragon (Samhain issue) 8. See also Wilma George and Brunsdon Yapp, The Naming of the Beasts: Natural History in the Medieval Bestiary (London: Duckworth, 1991) 170.

${ }^{66}$ Daniel Boorstin, The Mysterious Science Of Law (Gloucester, Mass: Peter Smith, 1973) 25.

${ }^{67}$ Id at 104. See also Blackstone supra note 58 vol 3, Of Private Wrongs 268. 
68 Britton supra note 50 at paragraph 19.

69 Bracton supra note 45 vol 3 at 221.

${ }^{70}$ Id vol 2 at 31, vol 4 at 361; Britton supra note 50, para 19.

${ }^{71}$ Foucault supra note 2 at 66.

72 Swinburne supra note 53 at 168.

73 Id at 169.

${ }^{74}$ Coke supra note 45 vol 3 at 59 .

75 Ambroise Pare, On Monsters and Marvels (1573) (trans Janis L. Pallister) (Chicago: Chicago University Press).

${ }^{76}$ Lorraine Daston, 'Marvellous Facts and Miraculous Evidence in Early Modern Europe' (1991) Critical Inquiry 93, 112.

77 Blackstone supra note 58 vol 2 at 247.

78 Glanville Williams, The Sanctity of Life and the Criminal Law (New York: Alfred A. Knopf, 1972) 21.

${ }^{79}$ Blackstone supra note 58 vol 2 at 247.

80 Wayne Morrison, Introduction to Commentaries on the Laws of England vol 1 (London: Cavendish, 2001) cxiv-cxviii.

81 See, for example, Henry John Stephen, New Commentaries on the Laws of England (Partly Founded on Blackstone) $2^{\text {nd }}$ edn vols 1-4 (London: Henry Butterworth, 1848) vol 1 at viii.

82 Keith Thomas, Man And The Natural World: A History Of Modern Sensibility (London: Lane, 1983) 122; Manfred Pfister, 'Man's Distinctive Mark: Paradoxical Distinctions between Man and his Bestial Other' in E. Lehmann and B. Lenz (eds) Early Modern Texts in Telling Stories (Amsterdam: B.R. Gruner, 1992) 17, 21. However, at least one scholar has dated this development to the late Middle Ages (Joyce E. Salisbury, The Beast Within: Animals in The Middle Ages (London: Routledge, 1994) 2).

83 Thomas id at 122.

${ }^{84}$ Of course, the figure of bestial man did engender concern within popular culture and some non-legal discourses of the period (see, for example, Salisbury supra note 82; Richard Bernheimer, Wild Men in the Middle Ages: A Study of Art, Sentiment and Demonology (London: Octagon Books, 1970)). 